\title{
Learning, and Understanding of Public History as Part of the Professional Historical Education at German Universities
}

\section{Introduction and Outline}

Today Public History may be viewed as a particularly promising area of academic teaching and research at German universities within the science of history. Progress and form of its institutionalization have so far mostly followed the US-American model. ${ }^{1}$ Certainly, Public History has been established internationally as an academic research and teaching discipline. ${ }^{2}$ However, in the German Higher Education system Public History is still in a kind of standby position: The institutionalization of Public History had in recent years been rooted with a noticeably increasing number in professorships, staff positions, university courses and areas of focus. So far, however, it has not been possible to determine to what extent this trend has contributed to the establishment of Public History as a generally accepted part of historical research in Germany. A number of important questions have not yet been answered: They relate on the one hand to content, theoretical and methodological boundaries of Public History. ${ }^{3}$ On the other hand they refer to the actors involved: Who exactly are Public Historians? Do they differ from 'normal' historians and, if so, in which form? ${ }^{4}$ What about the many contact zones between the science of history and the public? And how can we overcome

1 For a German perspective on the topic see Simone Rauthe, Public History in den USA und der Bundesrepublik (Essen: Klartext, 2001). and Irmgard Zündorf, Public History in den USA und der Bundesrepublik. Docupedia-Zeitgeschichte 11.2.2010, accessed May 1, 2016, http://docupedia.de / zg/Public_History?oldid=106468.

2 See Serge Noiret, “Internationalizing Public History,” Public History Weekly 2, no 34 (2014), accessed May 1, 2016, doi: 10.1515/phw-2014-2647.

3 The few attempts to bring theoretical and practical approaches of Public History to a common denominator at least for the German university system have not been able to solve the existing deficit in theory. See Marko Demantowsky, "Public History - Sublation of a German Debate?, “ Public History Weekly 3, no. 2 (2015), accessed May 1, 2016, doi: 10.1515/phw-2015-3292. For internal differentiations and delimitations see Jacqueline Nießer and Juliane Tomann, eds., Angewandte Geschichte. Neue Perspektiven auf Geschichte in der Öffentlichkeit (Paderborn: Schöningh, 2014).

4 See Cord Arendes, “Who We Are: Public Historians as Multiple Personalities?,” Public History Weekly 3, no. 36 (2015), accessed May 1, 2016, doi: 10.1515/phw-2015-4908. 
the well-known communicative deficits which can be stated for both sides academia and the public? Herewith, albeit plentiful hidden, a classical "whatis-question" is formulated, namely in regard to aims, limits, and challenges of a German Public History, both based at the University and settled in professional historical research. "What-is-questions" usually mark dissatisfactions with lines of argument which have become too common. They therefore also point to a necessary (re-)positioning or even a fundamental change of attitude. Overall, one must ask whether a statement made by the Berlin historian Martin Sabrow on the disciplinary nature of Contemporary History is also valid for Public History: "Its profile is of peculiar blur." ${ }^{5}$ But neither self-positioning nor opening to new perspectives of knowledge is possible without clarification of one's own point of view: With reference to different approaches of history or with reference to related disciplines in the humanities and/or to a non-academic public. Without such a clarification, it might not come to a shift and an exceeding of the existing limitations. Zones of enhanced contact may only occur when the boundaries between academia and the public are sufficiently open or if the overlaps and not the separations are stressed. Public History aims to remove the existing limitations in spaces of thought and communication. This essay would like to sharpen and clarify the scope of Public History: First, it tries to determine the status quo of Public History in Germany: This is measured on the one hand in regard to its position in the wider context of professional historical education at German universities. On the other hand in regard to its position within history as an academic discipline as well as within the non-academic public. After clarifying these basic conditions, secondly, a different approach to Public History will be introduced: not as a theoretical or ideal type, but by using a concrete example which comes directly from the daily work of teaching and research at Heidelberg University. ${ }^{6}$ Above all, the proximity to practice and the public should be stressed. Thirdly, and a last important goal of this self-positioning, is the approach to the suspected intersections of Public History between research and teaching, and between practice and the public. What aspects of their everyday work specify historians as Public Historians? By answering these questions, it should be possible to overcome the previous attempts to interpret Public History in Germany, which were especially inspired by Contemporary History and/or History Didactics.

\footnotetext{
5 Martin Sabrow, "Einleitung,“ in Zeitgeschichte schreiben. Von der Verständigung über die Vergangenheit in der Gegenwart, ed., Martin Sabrow (Göttingen: Wallstein, 2014), 7.

6 The author of this article is Professor of Applied History - Public History at Heidelberg University. For both, ongoing and completed research projects with a main focus on practice see www.uni-heidelberg.de/fakultaeten/philosophie/zegk/histsem/mitglieder/lsarendes_forschung. html. accessed May 1, 2016.
} 


\section{Public History: Status quo in Germany}

Closely intertwined with the development and success of Public History is the noticeable and growing worldwide interest in historical knowledge and in history since the 1970s. This is reflected first and foremost in a quantitative increase in both the demand for and the range of history-promoting products in the wider public. The past has become something like a possession of our everyday life: It is almost a commonplace and yet it is relevant for our identity. At a first glance it makes not much of a difference whether this trend concerns traditional cultural activities like history museums, ${ }^{7}$ memorials, documentaries, and non-fiction books ${ }^{8}$ or flourishing trends like medieval fairs, re-enactments of historical battles as formats of living history, ${ }^{9}$ computer games, or comics. ${ }^{10}$ History has an important function as a form of social entertainment ${ }^{11}$; it is used as an argument in politics and as an effective component of the culture of remembrance. ${ }^{12}$ Not at least shown by the keyword "history management" (Vergangenheitsbewirtschaftung), it has also become an important economic factor. ${ }^{13}$ But Public History in terms of a public history not only follows the lines of the growing historical interest. It is in its quintessence primarily a response to the rise in public demand for historical content and to the challenges and opportunities for the discipline of history linked to this development. ${ }^{14}$ Especially during the last five years, the

7 Rosmarie Beier-de Haan, Erinnerte Geschichte - Inszenierte Geschichte. Ausstellungen und Museen in der Zweiten Moderne (Frankfurt a.M.: Suhrkamp, 2005).

8 For short introductions to different fields of history in the public see Sabine Horn and Michael Sauer, eds., Geschichte und Öffentlichkeit. Orte - Medien - Institutionen (Göttingen: Vandenhoeck \& Ruprecht (UTB), 2009).

9 Wolfgang Hochbruck, Geschichtstheater. Formen der „Living History“. Eine Typologie (Bielefeld: Transcript, 2013). Miriam Sénécheau and Stefanie Samida, Living History als Gegenstand Historischen Lernens. Begriffe - Problemfelder - Materialien (Stuttgart: Kohlhammer, 2015).

10 Barbara Korte and Sylvia Paletschek, eds., History goes Pop. Zur Repräsentation von Geschichte und populären Medien und Genres (Bielefeld: Transcript, 2009).

11 Wolfgang Hardtwig, Verlust der Geschichte - oder wie unterhaltsam ist die Vergangenheit? (Berlin: Vergangenheitsverlag, 2010).

12 Sharon Macdonald, Memorylands. Heritage and Identity in Europe Today (London/New York: Routledge, 2013).

13 Wolfgang Hardtwig and Alexander Schug, eds., History Sells! Angewandte Geschichte als Wissenschaft und Markt (Stuttgart: Steiner Verlag, 2009). Christoph Kühberger and Andreas Pudlat, eds., Vergangenheitsbewirtschaftung. Public History zwischen Wirtschaft und Wissenschaft (Innsbruck: StudienVerlag, 2012).

14 Some examples for recent attempts of linking the interests from recipients from inside and outside academia in Germany can be find in Thorsten Logge, "Public History in Germany: Challenges and Opportunities," German Studies Review 39, no. 1 (2016). 
US-American model ${ }^{15}$ has been copied at German universities, which are implementing it in different ways, depending on their organizational requirements and policies. This can take the form of anything from individual classes ${ }^{16}$ all the way to entire Masters-programs. ${ }^{17}$ Depending on the focus of each university, the offered courses are implemented by creating new teaching positions at the interfaces between history and profession, ${ }^{18}$ hiring lecturers to teach additional classes in this field, or establishing subject-related or specialized professorships for Public History, Applied History and/or History Didactics. ${ }^{19}$ As a teaching and

15 In the US the term describes different workspaces for academically trained historians beyond university and school (non-teaching careers). In addition to the aim of strengthening the employability of graduate students, Public History in the US always has been a form of active demarcation of the academic historians: As a movement from below, as an own discipline and as a contractor of both public and private sector services. The unity of historical research and dissemination of historical knowledge has been maintained in this context only slightly.

16 Theseare mostly complementary courses in the new B.A. and M.A. degree programs with respect to "practical relevance" (Praxisrelevanz), for "transversal skills" (übergreifende Kompetenzen) or "career-related additional qualifications" (berufsfeldbezogene Zusatzqialifikationen).

17 A comprehensive overview that lists all such offers does not yet exist. For a straight Public History Master Program see the "Public History Master" at the FU Berlin, www.geschkult. fu-berlin.de/e/phm/index.html, accessed May 1, 2016. In the meantime, at least two further MA courses in Public History were established. The Master Program "Public History" at the University of Bochum (since winter term 2017/18), https://www.ruhr-uni-bochum.de/public-history/index. html.en, and, starting in winter term 2018/19, the Master Program "Public History and Cultural Education” at the University of Regensburg, http://www.uni-regensburg.de/sprache-literaturkultur/vergleichende-kulturwissenschaft/studium/studiengaenge/master-public-history-undkulturvermittlung/index.html, accessed July 16, 2018. A comprehensive overview that lists all such offers does not yet exist. For a straight Public History Master Program see the "Public History Master” at the FU Berlin, www.geschkult.fu-berlin.de/e/phm/index.html, accessed May 1, 2016. In the meantime, at least two further MA courses in Public History were established. The Master Program "Public History" at the University of Bochum (since winter term 2017/18), https://www. ruhr-uni-bochum.de/public-history/index.html.en, and, starting in winter term 2018/19, the Master Program "Public History and Cultural Education" at the University of Regensburg, http:// www.uni-regensburg.de/sprache-literatur-kultur/vergleichende-kulturwissenschaft/studium/ studiengaenge/master-public-history-und-kulturvermittlung/index.html, accessed July 16, 2018. 18 Two examples among many others are the "Schnittstelle Studium und Beruf" at the University of Muenster, www.uni-muenster.de/Geschichte/histsem/LG-G/Organisation/krull.html and the "Arbeitsbereich Public History" at the University of Hamburg, www.geschichte.uni-hamburg.de/ arbeitsbereiche/public-history.html, accessed May 1, 2016.

19 In chronological order of the vacancies and/or staffing: Professorship of "Applied History -Public History" at Heidelberg University, https://www.uni-heidelberg.de/fakultaeten/philosophie/zegk/ histsem/mitglieder/arendes.html; Assistant-(Junior-)Professor of "Public History" at the University of Cologne, http://histsem2.phil-fak.uni-koeln.de/gundermann.html; Professorship of "History Didactics and Public History” at the LMU Munich, https://www.did.geschichte.uni-muenchen.de/ personen/lehrstuhlinhaber/prof_-dr_-michele-barricelli/index.html; Assistant-(Junior-)Professor of 
training discipline, Public History does seem to be helping historians to meet the growing demand for answers to questions related to their area of study. Besides, the German Public History also has a functioning communicative infrastructure for their researchers. Applying classical criteria of the sociology of knowledge to identify and characterize scholarly and scientific disciplines, such a "sufficiently homogeneous" communicative space, ${ }^{20}$ can be considered as a further step on the road towards establishing Public History as an important and sustainable part of historical education at German universities: The most important institutions enabling this broad communication among the various actors involved include the multilingual blog journal "Public History Weekly"21 and, in particular, the "Working Group on Applied History and Public History" of the German Association of Historians. ${ }^{22}$ As a teaching and education field, Public History at least at a first glance - has succeeded to provide answers to many problems associated with the increasing demand for historical knowledge and which are directly linked to the science of history.

As part of this incipient institutionalization there are three aspects which should be highlighted and discussed: The field is characterized on the one hand by a staff and research structure, which is marked by differing denominations of the professorships, in regard to which a clear trend in favor of the term "Public History" can be identified. ${ }^{23}$ On the other hand, the emphasis on the field of History Didactics catches the eye: Only the Heidelberg professorship and the Berlin Master's program are based on a predominantly professional academic anchoring and are not explicitly defined as a part of the field of didactics. Besides, it plays no role, whether new Assistant (i.e. Junior) professorships

"Public History and historical learning" at the University of Flensburg, https://www.uni-flensburg.de/ geschichte/wer-wir-sind/personen/prof-dr-astrid-schwabe/; Assistant-(Junior-)Professor of "Public History" at the University of Hamburg, https://www.geschichte.uni-hamburg.de/arbeitsbereiche/ public-history/personen/logge.html; Assistant-(Junior-)Professor "History Didactics" at the University of Bochum, http://www.ruhr-uni-bochum.de/histdidaktik/Mitarbeiter/bunnenberg.html, and Professorship of "History Didactics and Public History" at the University of Tübingen, https://www. uni-tuebingen.de/fakultaeten/philosophische-fakultaet/fachbereiche/geschichtswissenschaft/seminareinstitute/geschichtsdidaktik-und-public-history/institut.html, accessed July 16, 2018. None of the three Assistant-(Junior-)Professors includes a tenure track option.

20 Rudolf Stichweh, "Differenzierung der Wissenschaft, “Zeitschrift für Soziologie 8, no. 1 (1979): $83-85$.

21 https://public-history-weekly.degruyter.com, accessed May 1, 2016.

22 www.historikerverband.de/arbeitsgruppen/ag-angewandte-geschichte.html, accessed May 1, 2016.

23 For details see footnote 19. With the exception of Heidelberg University (professorship for "Applied History - Public History"), all other professorships are limited to the term "Public History". 
were established or existing professional didactics professorships extended or their denominations changed. This focus has its specific reasons: The Englishlanguage Public History discourse does not incorporate History Didactics (i.e. History Teaching) in its definition - or at least only very marginal. ${ }^{24}$ In Germany, however, a strong connecting line refers to the didactic discussions of the $1970 \mathrm{~s}$ and 1980s. Professional didactics approached the science of history and ventured a quite early arrival in the public ${ }^{25}$ - by a more intensive and broader transfer of knowledge. The widely discussed theoretical concepts in History Didactics like außerschulische Öffentlichkeit (extracurricular public), Geschichtsbewusstsein (historical consciousness) or Geschichtskultur (historical culture) refer to the existing potentials of reasoning and communication of scientific history in its relationship with the public. They all already point to a crucial aspect of Public History, namely the mutual involvement of readers, viewers, listeners, or decision-makers in discussing the standards, methods and contents of historicalacademic work: A procedure that perceives the constant transfer of historical knowledge as a reciprocal process - not as a one-way street. Public History in Germany shows another special feature: Many actors involved in the field attributed it to twentieth century history. Martin Sabrow for example assigns Public History undoubtedly to Contemporary History: As a historical "field of work" which "tries to integrate the tension of aim-oriented science free of purpose, from basic and applied research, knowledge acquisition and knowledge transfer in the field itself." ${ }^{26}$ However, although the public interest in Contemporary History and/or the history of the twentieth century is particularly large, ${ }^{27}$ the increased importance of history in the public is also true for other epochs ${ }^{28}$ and neighboring historically or cultural-academically working disciplines. ${ }^{29}$ But is it all

24 See Demantowsky, Public History.

25 Siegfried Quandt, "Öffentlichkeit,“ in Handbuch der Geschichtsdidaktik, eds. Klaus Bergmann, Annette Kuhn, Jörn Rüsen, and Gerhard Schneider (Düsseldorf: Schwann, 1979).

26 Sabrow, "Einleitung,“ 7. Hanno Hochmuth and Irmgard Zündorf, "Public History als Zeitgeschichte,“ Docupedia-Zeitgeschichte 21.5.2015, accessed May 1, 2016, http://docupedia.de/ zg/Public_History_als_Zeitgeschichte?oldid=107578.

27 Alexander Nützenadel and Wolfgang Schieder, "Zeitgeschichtsforschung in Europa. Einleitende Überlegungen, "in Zeitgeschichte als Problem. Nationale Traditionen und Perspektiven der Forschung in Europa, eds. Alexander Nützenadel and Wolfgang Schieder (Göttingen: Vandenhoeck \& Ruprecht, 2004), 7-8.

28 Angelos Chaniotis, Annika Kuhn, and Christina Kuhn, eds., Applied Classics. Comparisons, Constructs, Controversies (Stuttgart: Steiner Verlag, 2009).

29 Hans-Joachim Gehrke and Miriam Sénécheau, eds., Geschichte, Archäologie, Öffentlichkeit. Für einen neuen Dialog zwischen Wissenschaft und Medien. Standpunkte aus Forschung und Praxis (Bielefeld: Transcript, 2010). Stefanie Samida, "Public History als Historische 
disadvantageous when the term "Public History"- in the German context still far more than in the American - is still waiting for a clear definition up to today? Can this supposed deficit not be turned into something positive? Is it not its openness ${ }^{30}$ that makes Public History able to connect to all sorts of claims and differing interpretations and concepts within the scope of a science of history which is modern, interdisciplinary, and committed to the field of cultural studies?

\section{Public History: Education, Practice, and Research}

The term "public" refers to the context, in which historians do their daily work and which is likely to influence their methods, contents, and interpretations alike. The term "history" emphasizes the disciplinary standards that apply without a direct or even an indirect reference to places and audiences. ${ }^{31}$ "Public" unfortunately in many cases is synonymous for a generalized and at the same time anonymous and passive public to which the products of the work of the historians are 'offered'. ${ }^{32}$ The focus of an innovative Public History should instead be laid on the common working processes. Doing so, Public History is defined less about its products (texts, websites, etc.), but by its procedural character: as a reflexive practice or application of scientific history. ${ }^{33}$ Public History then does not act primarily as an agent in the framework of a common practice with the public, but is above all asking questions that deal with the relations within and the motivations for communication with all participants in its projects. This special understanding of Public History is able to decisively bridge the gap prevalent in the historic landscape: Its interpretations combine professional academic work with everyday life while also respecting partnerships with non-university actors and the public - through the act of balancing research and public interest. Public History therefore can provide the necessary contact zones for a scientific approach to

Kulturwissenschaft: Ein Plädoyer,“ Docupedia-Zeitgeschichte, 17.6.2014, accessed May 1, 2016, https://docupedia.de/zg/Public_History_als_Historische_Kultuerwissenschaft.

30 Thomas Thiemeyer, "Inszenierung, “ in Museen verstehen. Begriffe der Theorie und Praxis, eds., Heike Gfrereis, Thomas Thiemeyer, and Bernhard Tschofen (Göttingen: Wallstein, 2015), 59. 31 Denise D. Meringolo, Museums, Monuments and national parks. Toward a New Genealogy of Public History (Armherst/Boston: University of Massachusetts Press, 2012), iv, xvi.

32 Public refers to the macroscopic audience instead of the microscopic audience or the given limitations of the scientific community. See Phyllis K. Leffler and Joseph Brent, Public and Academic History: A Philosophy and Paradigm (Malabar: Robert E. Krieger, 1990), 15-20.

33 Rebecca Conrad, "Public History as a Reflective Practice," The Public Historian 28, no. 1 (2006). 
history in the future. What is specific to Public History, which is not meant to be a popularized form of historiography or a typical contemporary variant of remembrance culture? Public History in the university classroom does not fit easily into the traditional canon: It's transverse to history's traditional structure, above all the temporal focus or the sectoral division of the discipline. But it's capable to make the necessary connections. Public History must not confine itself to comply with demands for competency profiles, career guidance or key skills for students which are to be found in almost all scientific and educational position papers today. The aim is a comprehensive professionalization, not only the preparation of apprenticeship. Public History, therefore, needs a new, an extended perspective: It integrates the results of the entire history and it provides the necessary modes of communication between history as a science and individual social groups. Let us follow two basic assumptions: Public History can develop its full potential only if it constantly reflects its close relation to practice (public) in a critical manner. Additionally, Public History should simultaneously always be defined actively as a research field (history). Its market value of cognitive experiences, good arguments, and reflection depends strongly on the reference to both, practice and research. Objectives and challenges of Public History can be summarized with the ideas of professionalization, proximity to practice, and research activities - all three of which include students and the general public.

What does this mean for the everyday university life of research and teaching? So far, the research activity of students is closely linked to drafting theses or takes place as a "companion" of the research of their lecturers and professors. Instead students should make their own authentic experiences in research, develop a scientific curiosity and recognize their own research interests as early as possible. Moreover, this experience should offer a realistic insight into the work of historians. Such a concept can only be implemented successfully if the university maintains a relationship to the professional reality of the daily work of historians. This relationship to the reality requires the development and implementation of new teaching formats centering on specific questions. The core of course forms related to Public History should be the project related teaching (Projektbzw. Praxisseminar) ${ }^{34}$ : Especially project related teaching is characterized by

34 For the field of of project related teaching in Heidelberg see Angela Siebold and Cord Arendes, "Historisch Forschen - Professionell vermitteln. Ziele und Herausforderungen einer universitären Public History,“ in Projektlehre im Geschichtsstudium. Verortungen, Praxisberichte und Perspektiven, eds., Ulrike Senger, Yvonne Robel, and Thorsten Logge (Bielefeld: Bertelsmann, 2015). For general information on this topic see Ulrike Senger, Yvonne Robel, and Thorsten Logge, eds., Projektlehre im Geschichtsstudium. Verortungen, Praxisberichte und Perspektiven (Bielefeld: Bertelsmann, 2015). 
immediate feedback on current research questions. It doesn't merely build an alternative to research because the students themselves are an active part of the research process itself. After an independent scientific analysis of a topic, the next steps are always to think about the necessary aspects of a successful knowledge transfer and the reflection of the social relevance, limits, and difficulties in dealing with historical themes in the public. At Heidelberg University, regional and local historical research with a medium range have emerged as a focus of Public History through a series of partnerships with non-university partners. ${ }^{35}$ Right here the function of Public History as an instance of reflection for the relationship between academia and the public has great effects: First, let us consider the connection to the public: The special appeal of regional or local history is that their locations are well-known and their concepts sound familiar. This comes with the great opportunity to situate oneself historically, especially in times of uncertain identities. This means that the experience not only stimulates the audience. It also has the consequence that in many places the involved researchers and authors from outside of academia are engaged to lay their own historical roots free. Secondly, we can find the connection to academia: Today's public image of research, for example about National Socialism, is still largely influenced by political, social, and legal aspects centered on the national level. There are no or only few explicit regional or local references. The reception in the media moves almost entirely at the level of prestigious public events, people, and institutions. A proper consideration of regional or local history will possibly take place locally and will not always achieve the research echo it deserves. It therefore seems essential to check the rough structures and findings which worked out

35 In detail: A research project concerning "Forced labor in the city of Schwetzingen, 1939-1945" in cooperation with the city and the city archives, https://www.uni-heidelberg.de/fakultaeten/ philosophie/zegk/histsem/forschung/HPH_Schwetzingen.html; the exhibition “Heidelberg's wild 1970s" with student support and in cooperation with the city's historical museum (Kurpfälzisches Museum Heidelberg), https://www.uni-heidelberg.de/fakultaeten/philosophie/ zegk/histsem/mitglieder/lsarendes_forschung_1970er.html; a student based analyses of the visitors resonance of both the 5th and 6th International Fotofestival Mannheim-LudwigshafenHeidelberg ("MAGNUM: TRANS-TERRITORIES" 2013 and "[7P] - [7] Places [7] Precarious Fields" 2015) in cooperation with the Cultural Office of the city of Mannheim; a partnership with two high schools in the Heidelberg region concerning the project "Locally Encounters - Administrative History and NS everyday life" with a sponsorship of the Robert-Bosch-Endowment, https://www. uni-heidelberg.de/fakultaeten/philosophie/zegk/histsem/mitglieder/lsarendes_forschung_ denkwerk.html, and the teaching project series "Public History \& Theater", which combines independent research by students with the communication of their research results, https:// www.uni-heidelberg.de/fakultaeten/philosophie/zegk/histsem/mitglieder/lsarendes_theater. html, accessed July 16, 2018. 
at the national historical grid in micro-regional studies to determine the different levels, and if necessary, to add new research questions. These questions should be developed in dialogue with the directly and/or indirectly affected audiences. Such a "glance into daily worlds" has the advantage that it allows historians to dive deep into contemporary social relations and regard them not only as "sideshows" of history: This is especially true for those local actors who otherwise would have aroused only little or no interest in history, but whose framework as well as their respective individual maneuvers are able to be used as examples for the analyzed period. The collaboration with archivists, citizens, or representatives of local educational institutions also widens the views of the researchers involved. At the same time it usually becomes clear what issues would be better moved aside in the discourse or which special interests connected to our own history predominate in the public. And a final important aspect: Especially the students, as future historians, were yet to be integrated in these processes as far as possible during their studies. Several semesters of practiced Public History at Heidelberg University have shown that students could benefit immensely if they can make their own authentic and hopefully realistic experiences with the daily work of historians. And this is foremost achieved by research-based and projectrelated teaching. Project related teaching conveys, based on research results, additional skills; especially practical skills that are existential for later professional work life. These include assessing one's own role in a team or just to be able to process texts or other products of research in a relatively short time and based on clear deadlines. A mere by-product are contacts which are being created between students and potential future employers in non-university education, in public institutions, or in the private sector. This last aspect also includes information about the ethical aspects of doing historical research both in the university and the public sphere. ${ }^{36}$ Students in courses with project related teaching don't act and feel like learners or even as pupils, but as researchers and scientists. In this way they develop a professionalized identity as historians as early as possible. To study Public History, therefore, means primarily to learn how to "do research": at realistic conditions, in real time, and in a sphere which goes beyond the aspects of the scientific evaluation. Public History - as a concept - represents an important part of academic research. It reflects and analyzes the challenges and opportunities of the increased demand for history or historical knowledge. It promotes its self-image in the public as well as its position in the humanities and social

36 Cord Arendes and Angela Siebold, "Zwischen akademischer Berufung und privatwirtschaftlichem Beruf: Für eine Debatte um Ethik- und Verhaltenskodizes in der historischen Profession,“ Geschichte in Wissenschaft und Unterricht 66, no. 3-4 (2015). 
sciences. It is about the many forms of dialogue between science and society, the elimination of existing barriers between scientific experts and politically conscious and historically interested citizens.

\section{Public History: Building Bridges to the Public}

To raise a final question: Which of the personality profiles described above is able to embrace both the public relevance and the research and scholarly aspects of public history? Or, to put it another way, which of them could make it easier for scholars and lay persons to join forces and spawn new types of dialog while dismantling barriers among historians, practitioners, and interested members of the public? One answer might be to merge the multiple personalities of historians, who bring together "the best of all worlds" and are also able, at the very least, to comprehend the work of everyone else involved in a given project. ${ }^{37}$ Although practical experience on the other side of the fence is good for everyone, it is not advisable for public historians to play the role of "daring pioneers" or "dangerous adventurers". ${ }^{38}$ In the view of the progressive specialization and differentiation of historians, this statement may seem anachronistic. However, in terms of the goal of stressing and strengthening the character of Public History as a process that involves reflecting on or applying history, it certainly deserves consideration. It is not necessary to invent a "new kind of person" - many historians already situate themselves in the hybrid zone ${ }^{39}$ between research and teaching, on the one hand, and between practice and becoming involved with the public, on the other. It is common for them to play widely diverging roles: as academic historians and, specifically, for the most part, as contemporary historians whose work, amongst other things, focuses on the culture of history and remembrance; as public historians whose principal goals are to acquaint the public with the processes and mechanisms involved in studying the past and to build bridges for their audience, while, in many cases, also being actively involved as experts in practical projects, such as exhibitions. This is not an appeal to define public historians as multiple personalities. Rather, it calls on all players to reflect on the different and changing roles they perform: as historians who preserve their core activity of research-based

37 See Arendes, Who We Are.

38 Henry Rousso, “Applied History, or The Historian as Miracle-Worker," The Public Historian 6, no. 4 (1984): 65.

39 For a different reading of the term "hybrid" see Matthew Flinders, "The Tyranny of Relevance and the Art of Translation,” Political Studies Review 11 (2013): 160-161, 165. 
scholarship, and as practitioners who also apply scholarly methods. At the end of the day, perhaps, the described hybrid personality structure - firmly anchored in historical studies yet, at the same time, practical in its orientation - will turn out to be exactly what is needed to ensure the future of historical studies in the twenty-first century. ${ }^{40}$ To establish a new field of work in academic teaching and research within the German university system is a multifaceted and exciting task. A concept that wishes to form its own brand also faces many different claims that sometimes are difficult to redeem. Because of its close relation to practice and research, Public History is able to become a relevant concept for the field of history research. As a new concept it is independent within the discipline and capable of gaining reputation. Beyond the narrow limits of a specialization it is also communicable to a broader public. Science requires a public..$^{41}$ It is the place, where its results were discussed. The public purpose is not only imposed from the outside but must also be thought within the science of history itself. In the crucial processes of knowledge creation and knowledge transfer Public History can act as an interpreter or even as a "translator" 42 in historical thinking and therefore build the necessary bridges to the public.

\section{Literature cited}

Arendes, Cord. Who We Are: Public Historians as Multiple Personalities? Public History Weekly 3, no. 36 (2015). Accessed May 1, 2016. doi: 10.1515/phw-2015-4908.

Arendes, Cord and Angela Siebold. Zwischen akademischer Berufung und privatwirtschaftlichem Beruf: Für eine Debatte um Ethik- und Verhaltenskodizes in der historischen Profession. Geschichte in Wissenschaft und Unterricht 66, no. 3-4 (2015): 152-166.

Beier-de Haan, Rosmarie. Erinnerte Geschichte - Inszenierte Geschichte. Ausstellungen und Museen in der Zweiten Moderne. Frankfurt a.M.: Suhrkamp, 2005.

Chaniotis, Angelos, Annika Kuhn, and Christina Kuhn, eds. Applied Classics. Comparisons, Constructs, Controversies. Stuttgart: Steiner Verlag, 2009.

Conrad, Rebecca. Public History as a Reflective Practice. The Public Historian 28, no. 1 (2006): 9-13.

Demantowsky, Marko. Public History - Sublation of a German Debate?. Public History Weekly 3, no. 2 (2015). Accessed May 1, 2016. doi: 10.1515/phw-2015-3292.

Flinders, Matthew. The Tyranny of Relevance and the Art of Translation. Political Studies Review 11 (2013): 149-167.

40 See Arendes, Who We Are.

41 Ivan Karp, "Public Scholarship as Vocation," Arts and Humanities in Higher Education 11 (2012): 291-294.

42 Bernhard Pörksen, “Die Angst der Geisteswissenschaften vor den Medien,“ Pop. Kultur und Kritik 1, no. 1 (2012): 25. 
Gehrke, Hans-Joachim and Miriam Sénécheau, eds. Geschichte, Archäologie, Öffentlichkeit. Für einen neuen Dialog zwischen Wissenschaft und Medien. Standpunkte aus Forschung und Praxis. Bielefeld: Transcript, 2010.

Hardtwig, Wolfgang. Verlust der Geschichte - oder wie unterhaltsam ist die Vergangenheit? Berlin: Vergangenheitsverlag, 2010.

Hardtwig, Wolfgang and Alexander Schug, eds. History Sells! Angewandte Geschichte als Wissenschaft und Markt. Stuttgart: Steiner Verlag, 2009.

Hochbruck, Wolfgang. Geschichtstheater. Formen der „Living History“. Eine Typologie. Bielefeld: Transcript, 2013.

Hochmuth, Hanno and Irmgard Zündorf. Public History als Zeitgeschichte. DocupediaZeitgeschichte 21. 5.2015. Accessed May 1, 2016. http://docupedia.de/zg/Public_History_ als_Zeitgeschichte?oldid=107578.

Horn, Sabine and Michael Sauer, eds. Geschichte und Öffentlichkeit. Orte - Medien Institutionen. Göttingen: Vandenhoeck \& Ruprecht (UTB), 2009.

Karp, Ivan. Public Scholarship as Vocation. Arts and Humanities in Higher Education 11 (2012): 285-299.

Korte, Barbara and Sylvia Paletschek, eds. History goes Pop. Zur Repräsentation von Geschichte und populären Medien und Genres. Bielefeld: Transcript, 2009.

Kühberger, Christoph and Andreas Pudlat, eds. Vergangenheitsbewirtschaftung. Public History zwischen Wirtschaft und Wissenschaft. Innsbruck: StudienVerlag, 2012.

Leffler, Phyllis K. and Joseph Brent. Public and Academic History: A Philosophy and Paradigm. Malabar: Robert E. Krieger, 1990.

Logge, Thorsten. Public History in Germany: Challenges and Opportunities. German Studies Review 39, no. 1 (2016): 141-153.

Macdonald, Sharon. Memorylands. Heritage and Identity in Europe Today. London/New York: Routledge, 2013.

Meringolo, Denise D. Museums, Monuments and national parks. Toward a New Genealogy of Public History. Armherst/Boston: University of Massachusetts Press, 2012.

Nießer, Jacqueline and Juliane Tomann, eds. Angewandte Geschichte. Neue Perspektiven auf Geschichte in der Öffentlichkeit. Paderborn: Schöningh, 2014.

Noiret, Serge. Internationalizing Public History. Public History Weekly 2, no 34 (2014). Accessed May 1, 2016. doi: 10.1515/phw-2014-2647.

Nützenadel, Alexander and Wolfgang Schieder. Zeitgeschichtsforschung in Europa. Einleitende Überlegungen. In Zeitgeschichte als Problem. Nationale Traditionen und Perspektiven der Forschung in Europa, edited by Alexander Nützenadel and Wolfgang Schieder, 7-24. Göttingen: Vandenhoeck \& Ruprecht, 2004.

Pörksen, Bernhard. Die Angst der Geisteswissenschaften vor den Medien. Pop. Kultur und Kritik1, no. 1 (2012): 21-25.

Quandt, Siegfried. Öffentlichkeit. In Handbuch der Geschichtsdidaktik, edited by Klaus Bergmann, Annette Kuhn, Jörn Rüsen, and Gerhard Schneider, 53-56. Düsseldorf: Schwann, 1979.

Rauthe, Simone. Public History in den USA und der Bundesrepublik. Essen: Klartext, 2001.

Rousso, Henry. Applied History, or The Historian as Miracle-Worker. The Public Historian 6, no. 4 (1984): 65-85.

Sabrow, Martin. Einleitung. In Zeitgeschichte schreiben. Von der Verständigung über die Vergangenheit in der Gegenwart, edited by Martin Sabrow, 7-10. Göttingen: Wallstein, 2014. 
Samida, Stefanie. Public History als Historische Kulturwissenschaft: Ein Plädoyer. DocupediaZeitgeschichte, 17.6.2014. Accessed May 1, 2016. https//docupedia.de/zg/Public_History_ als_Historische_Kultuerwissenschaft.

Sénécheau, Miriam and Stefanie Samida. Living History als Gegenstand Historischen Lernens. Begriffe - Problemfelder - Materialien. Stuttgart: Kohlhammer, 2015.

Senger, Ulrike, Yvonne Robel, and Thorsten Logge, eds. Projektlehre im Geschichtsstudium. Verortungen, Praxisberichte und Perspektiven. Bielefeld: Bertelsmann, 2015.

Siebold, Angela and Cord Arendes. Historisch Forschen - Professionell vermitteln. Ziele und Herausforderungen einer universitären Public History. In Projektlehre im Geschichtsstudium. Verortungen, Praxisberichte und Perspektiven, edited by Ulrike Senger, Yvonne Robel, and Thorsten Logge, 105-116. Bielefeld: Bertelsmann, 2015.

Stichweh, Rudolf. Differenzierung der Wissenschaft. Zeitschrift für Soziologie 8, no. 1 (1979): 82-101.

Thiemeyer, Thomas. Inszenierung. In Museen verstehen. Begriffe der Theorie und Praxis, edited by Heike Gfrereis, Thomas Thiemeyer, and Bernhard Tschofen, 45-62. Göttingen: Wallstein, 2015.

Zündorf, Irmgard. Public History in den USA und der Bundesrepublik. Docupedia-Zeitgeschichte 11. 2.2010. Accessed May 1, 2016. http://docupedia.de/zg/Public_History?oldid=106468. 